http://ngtt.journals.ac.za

Mndende, Nokuzola

Icamagu Institute

\title{
Law and religion in South Africa: An African traditional perspective
}

\section{INTRODUCTION}

The discussion on the relationship between the law and religion in the South African context by somebody whose background and point of reference are based on the indigenous customary law of the land needs a special and honest approach. For the right approach, it is important that one has to be first honest to the inner self, to the religious community s/ he serves and then to the nation as a whole. I find it very difficult to compromise my inner self because I am expected to be politically correct even if I find flaws in the law of the land or I find some aspects of deliberate negligence in the implementation of the policies that are supposed to liberate all.

This paper will therefore be straight to the point and will not be subjected to any blind loyalty either to the Constitution as the supreme law of the country or to the government programs and their attitude towards indigenous religion. It must be noted that there is a wide gap between what is said in the Constitution and the implementation of the theories documented. The Constitution of the country as the supreme law of the land is, on some very important issues too superficial and accommodating at the expense of the previously and in-fact still disadvantaged religious communities.

Before engaging my topic on the response of African Traditional Religion regarding religion and the law in South Africa, there is a lot of unpacking that needs to be done with some terms and issues relating to religion as a discourse. It must be understood here that I will be talking about something that first still needs to be explained, as the religion had been characterized by distortions and misinterpretations. The history of what we now call African traditional religion itself still needs to be explained so that we can see how it fits in what is called religion and why in the past there were distortions and marginalization.

In the past, that is pre-1994, the year in which South Africa got independence from colonialism and apartheid; South Africa was incorrectly declared a mono-religious state. The indigenous religion of the country, African traditional religion (ATR) was then not even in the margin, it was relegated to a barbaric and outdated African culture with a secular spirituality. It was neither in state schools nor in any other government literature. Its practitioners had to perform the religion underground; hence even today some people regard it as a religion that is practiced by illiterate people of the rural areas. As a result up to this moment in time, to justify the religion's existence before any deliberations about it, one has to first explain what the religion is all about so as to convince the audience that it is in-fact a religion and not just an exclusive African culture or some form of African indigenous church or traditional healing.

Justice has never been fully done on the content of the religion as it had in most cases been written by scholars of religion who belonged to other faiths. These scholars who were infact Christian clergy (Mbiti, Idowu, Magesa, Parrinder, Olupona) to mention a few had an 
opportunity to be employed in the Departments of Religious Studies as Christian Theologians or as anthropologists. Because they felt the guilt of a displaced identity, they started to be sympathetic towards African traditional religion and started to write about it. In most cases they would be very apologetic as they were writing from a third person perspective. Their approach would either be from a western perspective or from a Judeo Christian perspective in definition of African concepts and practices. To appease their new spirituality which of course was also their source of income, they would make sure that they write in the past tense as if the religion is no longer practiced.

It will therefore be important for me in this debate to first briefly summarize which religious community embraces this African traditional religion I am talking about. This is also because some people include the Zionist churches or the Shembe ( Nazareth Baptist) church or traditional healers under the umbrella of ATR.

\section{African Traditional Religion: Definition and Scope}

As stated earlier, when one talks about African traditional religion; a synopsis of what the religion is all about is necessary. Below is a brief explanation of ATR so that when discussing its relationship with the contemporary law one is at least knowledgeable of what is it all about.

\subsection{Definition}

As the religion had to be part of the academic discourse, it had to be given an English name by those who were its early writers. The practitioners did not bother about the name because it was their way of life. This naming of the religion by outsiders could be noticed in the subjective nature of how it is portrayed; some calling it African Religion, or African Religion/s; some calling it African traditional religion or African traditional religion/s. Some call it Ancestor worship or Traditional African Religions or any name that had to suite their subjective interpretation in the study of the other. Because of what has been explained above, the name, content, and scope of the religion had been a matter of scrutiny by those whose wishes are to see it under the armpits of missionary religions. In this paper I will use the term that I myself find fitting my inner perspective which is African traditional religion.

There is a common definition by many scholars but below I have specifically cited Awolalu because he connects it with what is also done at this present moment. Awolalu explains African traditional religion as follows:

When we speak of African traditional religion we mean the indigenous religion of the Africans. It is the religion that has been handed down from generation to generation by the forebears of the present generation of Africans. It is not a fossil religion (a thing of the past) but a religion that Africans today have made theirs by living it and practicing it (cited by Dopamu 1991:21)

Idowu (1973) is very specific as he always includes the geographical area where the religion is practiced, which is Sub- Saharan.

\subsubsection{The use of "Traditional"}


Many practitioners of today are not sure whether to use 'traditional' or not. To them the use of the term may imply that it is the religion of the past, it is outdated and perhaps not capable of growing in comparison with the globalized world. The word "Traditional" may connote something that came into being a long time ago, something that could be interpreted as belonging to the era of 'primitivity'. I always advise the practitioners of African traditional religion that they should never be apologetic about their beliefs and practices. If to an outsider the term 'Traditional' connotes out-dated or whatever of the past, that should not be an issue because all these religions that boast of being progressive started centuries ago.

Idowu explains his use of 'traditional' by arguing as follows:

We have used this word to mean 'native', 'indigenous', that which is aboriginal or foundational, handed down from generation to generation, that which continues to be practiced by living men and women of today as religion of the forebears, not only as a heritage from the past, but also that which peoples of today have made theirs by living it and practicing it, that which for them connects the past with the present and upon which they base the connection between now and eternity with all that, spiritually, they hope or fear (Idowu, 1973:104)

Dopamu agrees with Idowu as he also argues as follows:

But African traditional religion is 'traditional' not because it is fossil, static and incapable of adaptation to new situations and changes, but because it is a religion that originated from the people's environment and on their soil. It is neither preached to them nor imported by them. Africans are not converted into it. Each person is born into it, lives it, practices it, and is proud to make it his own. Thus the word 'traditional' serves the purpose of distinguishing African religion from any other religion that has been brought to the people through missionary zeal and by propaganda (Dopamu, 1991:22)

\subsubsection{Is it a unified religion?}

The use of a plural (African traditional religions) is common in the writings of some scholars of the religion (Mbiti 1969, Okot 1970, Ferguson 1978, Westerlund 1991); but the majority of writers believes that there are many similarities between all the religious practices of the subSaharan Africa, something that makes the religion to be unified (Idowu 1973, Parrinder 1976, Dopamu 1991, Oladimeji 1980).

Despite the differences, there is an underlying identity in the indigenous religion of the subSaharan Africans which enables them to firmly argue with conviction that African traditional religion is a unified religion. There is a distinct regular rhythm in the general pattern of the people's beliefs and practices, and this is the common belief in the Creator. Though it is not necessary to justify whether the religion is singular or plural to those who are curious as it does not affect what the practitioners of the religion do, I will try to cite some scholars who agree that the religion is singular.

Idowu agrees with the use of singular in the religion as he argues:

We find in Africa, the real cohesive factor of religion is the living God and that without this

- 76 - NGTT Deel 54 Supplementum 4, 2013 
one factor; all things would fall to pieces. And it is this ground especially - this identical concept that we can speak of the religion of Africa in the singular (Idowu, 1973:104)

\section{Basic beliefs}

It is always important as explained earlier that, until the religion gets its full recognition and understanding that before engaging in any debate; one has to exercise some patience and explain the basic beliefs as if it is for the first time. Practitioners of the religion believe that their religion consists of spiritual beliefs and practices that are in their blood from birth. ATR practitioners believe that these beliefs and practices were handed down by their forebears and have survived over years, despite many changes that the continent had experienced. African traditional religion has no founder; it is believed that it was revealed to the first generation by the Creator. The first generation was given all the laws of how to live in harmony with the Creator, other human beings and with nature.

The story goes on to say that when the first generation died, they joined the spiritual world where the Creator lives. In other words, the death of the first generation marked the beginning of ancestors. Ancestors then, became the messengers of the Creator and also the supervisors of the physical world. The ancestors look at the welfare of the living, mainly through the elderly who in turn teaches the youth orally and through ritual performances. This is how the religion gets passed on from generation to generation.

There are therefore three basic beliefs and these are a belief in:

\subsection{The Creator}

People who practice African traditional religion believe in the existence of the Supernatural Power who created life and the earth. Neither science nor humans can explain the powers of this Creator. This Creator is the Spirit and is neither male nor female. Although the Spiritual Power is believed to be everywhere in creation, it is also believed that creation began in the Spiritual world. The Spiritual World is holy and it is where the laws, rituals and taboos that control the welfare of the physical world originated.

Africa is made up of many nations and each nation has a name or names for the Creator depending on the attributes that these communities believe are associated with the Creator. Some groups may share a common name

\subsection{Ancestors}

Ndlovu summarizes the concept of ancestors very concise when he says the following:

The ways of referring to ancestors in African languages point to five fundamental beliefs and principles which he explains as follows:

- A recognition that each human being is made up not only of flesh, bones and blood, but also has a spirit or soul.

- A belief that whereas the human body dies and decomposes, the spirit (soul) does not perish.

- An understanding that human relations, especially within the family circle, do not die, 
but their relationship, once established, goes on for ever.

- A recognition of the unique relationship that exists between the "creator Spirit" and the human; and

- The fact that in the light of the above, the spirits of the departed play the vital role of intermediaries (Ndlovu, 1991:34)

The spirits of those who have departed link the world of those who are alive with the world of the Creator. That is why they are believed to be playing the vital role of intermediaries.

\subsection{Communal life through ritual performances and social upbringing}

Rituals are extra-ordinary practices performed by the living for the spiritual world. Rituals are special gatherings of the clans aimed at communal religious practices. These are communal religious practices for some special purposes like the rites of passage, thanksgiving, divination rituals, and sometimes special rituals as requested by ancestors, like the bringing back of the spirit of some family member who died far away from home. In these religious gatherings the community acts out its various forms of worship. Through these rituals, unity and healing are achieved.

\section{Nature of African communities}

The basic unit constituting African communities is the family. Depending on the nature of the society, the family may be patrilineal or matrilineal.

Mbiti (1969) refers to this basic structure as one of as he claims that:

...kinship is reckoned through blood and betrothal (engagement and marriage). It is kinship which controls social relationships between people in a given community, it governs marital customs and regulations, it determines the behaviours of one individual towards another (Mbiti 1969:104).

During ritual performances the members of the clan come together and perform the ritual as a collective. An African community is understood as comprising of both the living and the departed members of the family- the ancestors. Mbiti, again explains this entity as follows:

The kinship system also extends vertically to include the departed and those yet to be born. It is part of traditional education for children in many African societies to learn the genealogies of their descent. The genealogy gives a sense of depth, historical belongingness, a feeling of deep rootedness and a sense of sacred obligation to extend the genealogical line (Mbiti, 1969:105)

Ancestors are believed to be intermediaries between the living members of the clan and their Creator/God. Every transformation in the development of the living individual must be announced publicly in order to officially inform both the living and the deceased members of the community. 


\section{Conflict of laws in South Africa: Foreign versus Indigenous}

In this document few sections of the Constitution will be cited and then a comparative analysis will be done so as to find out if these sections are implemented in an unprejudiced manner or not. It was earlier explained that the Constitution speaks well about all'South Africans' but one thing it never thought about was the affirmative action in religion. In the Bill of Rights in the Constitution of South Africa Section 9 speaks of 'equality for all', Section 15 speaks of'Freedom of Religion, belief and opinion', and Section 31 speaks of the Promotion and Protection of the Rights of Cultural, Religious and Linguistic Communities.

The question that needs to be asked is to check if there is really equality of all religions in South Africa, if there is freedom of religion and also to check if there is promotion and protection of the disadvantaged religion and culture. What I find interesting with the implementation of Section 31 of the Constitution for instance is that in two consecutive terms of office the chairpersons of the Commission for the Protection and Promotion of the rights of Cultural, Religious and Linguistic Communities are always Christians Reverends. That mentality on its own shows which religion is regarded as superior hence I still believe that South Africa has not shifted from the past. What is happening is just a replacement of white Christianity by a syncretistic form of Ibramic spirituality in Black cultural and apologetic skins.

\subsection{Violation of human/group rights}

In practice there is a lot of the violation of the rights of African traditional religion. ATR practitioners are denied the right to be independent. They are only accepted if they accept to be appendages of the Ibramic faiths, or if they accept to be labelled as 'Traditional healers', or if they accept that their form of spirituality is secular and is not at par with Ibramic faiths.

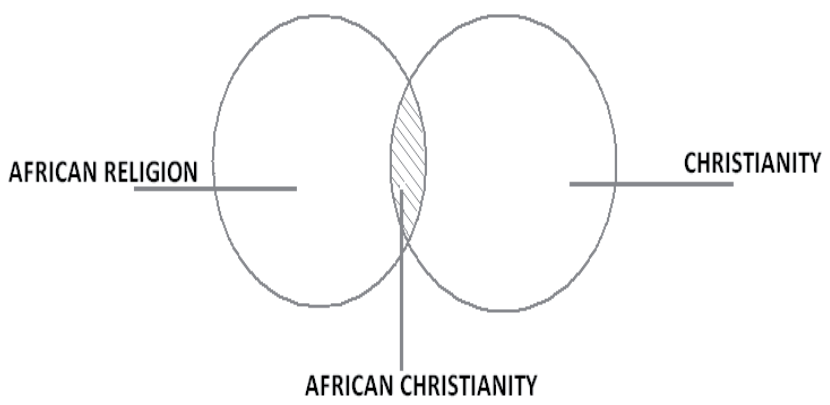

African traditional religion is always represented by people who belong to African Christianity or amagqirha/ngaka/sangomas (diviners) who practice syncretism as that is reflected in their regalia which depicts Christian symbols like crosses and stars but claiming to be messengers of the ancestors. The government is very biased towards the African converts and very oppressive, none caring and insensitive regarding the status of the practitioners of traditional spirituality. The government pretends as if these people do not exist anymore. 
The above explanation clearly indicates that although the Constitution speaks of equality, there are still lots of inequalities. In-fact it would practically be impossible to achieve equality when the ratio is enforced to be 9:1.

\subsection{Municipal by-laws}

There is an ongoing outcry by municipalities in big towns like Johannesburg, Cape Town and Durban where they say that there is lack of land for burial places in the cities. They claim that there no more burial land so South Africans must come up with solutions on how to bury their deceased. South Africans are then advised to tshisa (burn) their bodies after death as a solution to this lack of land in the cities. Strange enough in the very cities businesses are being built on a daily basis.

This cremation has not been communicated to the adherents of African traditional religion who invoke amathambo alele ukuthula (the Bones that are sleeping peacefully). The indigenous people who practice ATR hear about these policies on the electronic media when the powerful and the rich are convincing the listenership at home about their ludicrous decisions. Now they are forced to import this Far East tradition, which is cremation. I wonder if this is another form of encouraging them to do away with their belief systems and to invoke 'the ashes' (banqule ethuthwini)? According to ATR, a corpse cannot be kept in the homestead, whether it is in the form of bones or ashes, that is regarded as isimnyama (being under dark cloud). Cremation is out, no one can keep ashes at home, neither to sprinkle it in the sea or river; that is out of question. A deceased individual should be in a grave.

Graves in ATR are treated with great respect because it is believed that those whose remains are inside the graves are not dead but asleep. It is important for people to know where their dead relatives are buried because the bones of the deceased symbolize life. By knowing where the bones of the deceased relative are buried, one knows where the ancestor is 'lying'.

Another suggestion by the government is to bury one person over the other, like a wife over her husband, or a sun over his father. That is also ridiculous because when people speak over the grave, who will answer first?

When it comes to graves of African ancestors, even government officials are very careless, arrogant and are too subjective. What has been done in the sign post showing King Phalo's grave of AmaXhosa in Butterworth in the Eastern Cape for instance is ludicrous and could never been done to other religious leaders' grave. King Phalo died in 1775 before the arrival of Christianity in the Eastern Cape as the first missionary from the London Missionary society, Rev. Van der Kemp arrived in 1799. The sign post showing his grave is a complete distortion as it shows the cross of Jesus and those of the two criminals. 


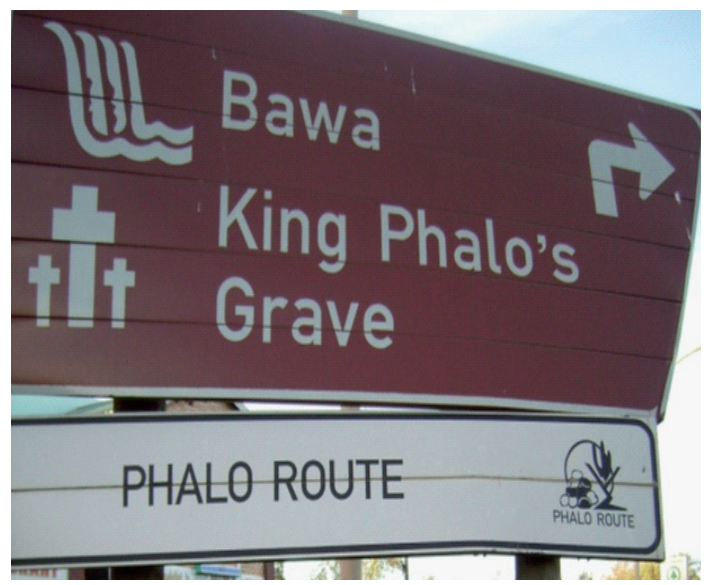

One would wonder if the same could ever be done in the sign post showing a Muslim grave or a Jewish grave, Never!

\subsection{Present South African calendar}

Though South Africa is declared a secular state, in reality it is still a Christian country. Having a closer look at the national calendar, only Christian holidays have remained public holidays, like Easter holidays and Christmas. The argument by the Government that there are two Christian holidays (Good Friday and Christmas) that are officially recognized in the country is incorrect and misleading. Historical reality points to five holidays as Easter Monday ( a day which follows Easter Sunday) and Boxing Day, (a day which follows Christmas) are always official national holidays and these days had in-fact both originated from Christianity. What happened to blindfolded people is to keep these Christian holidays (Easter Monday and Boxing Day) in the calendar as it happened before liberation but change their names to appear as if they were initiatives after 1994. They have just been transformed so as to appear as if they are inclusive yet they are extensions of Christianity.

The International Religious Freedom Report of 2004 also states that in South Africa:

Only Christian holidays, such as Christmas and Good Friday, are recognized as national religious holidays; however, members of other religious groups are allowed to celebrate their religious holidays without government interference.

Though the first statement is right when it says that 'members of other religious groups are allowed to celebrate their holidays without government interference' it is not true for ATR or perhaps they refer to other recognized religions like the Bahai, Buddhism, Hindu, Islam, and Judaism. No African Traditional holiday is recognized and government does not even cater for the practitioners of this religion when they want to be away from work, and ATR children are not excused from school as it is done with other religions. So this is misinformation and it needs to be corrected. 


\subsection{Meat Safety Act, 2000 (Act No. 40 of 2000) and Act No. 19 of 2002 on the Commission for the Promotion and Protection of the Rights of Cultural, Religious and Linguistic Communities Act, 2002).}

Though Act No.19 of 2002 speaks of the Promotion and Protection of the Rights of Cultural, Religious and Linguistic Communities the municipal By-laws dictate that animals should not be kept within the home for a period that exceeds twenty four hours. Section 147 of the Johannesburg Metropolitan's Public Health by-law, No. 180 of 2004 for instance states that an animal should be slaughtered in a position where the slaughtering cannot be observed by any person on neighbouring premises or any member of the public (Section 2b).

This is impossible for any ATR ritual because members of the public must come and witness that a particular ritual was performed.

To conclude, the laws regarding religion in South Africa is still biased, in-fact what has happened now is the replacement of a white oppressor by an African dictatorship and religious coercion. The content of the missionaries is now heavier and is channelled through fundamental capitalist churches which have mushroomed in thousands in the country. The main sermon of these churches is the demonization of ancestors and ATR. There is no protection of ATR; Sections 9, 15, and 31 do not apply when it comes to ATR. ATR is left to swim alone or to sink. It seems that a colonial heritage is still dictating the relationship between law and religion as far as African traditional religion is concerned.

\section{LIST OF REFERENCES}

Dopamu P A (1991). 'Towards understanding African Traditional Religion". In e m Uka Readings in African Traditional Religion. New York. Peter Lang

Du Toit C W \& Cedric Mayson (eds) (2006. Secular Spirituality as a Contextual Critique of Religion. UNISA:

Research Institute for Theology and Religion.

Ferguson J (1978). "African Religions". In Francis Clark \& John Ferguson, The Religious Perspective: African

Religions. Great Britain: The Open University

Idowu E Bolaji (1973). African Traditional Religion: A Definition. London: SCM Press

Magesa L (1998). African Religion: The Moral Traditions of Abundant Life. New York:Orbis Books

Mbiti J S (1969). African Religions and Philosophy. London: Heinemann

Mndende N (2006) African Spiritual Journey: Rites of Passage among the Xhosa speaking of South Africa.

Cape Town: Icamagu Institute

Mndende N (2009). Tears of Distress: Voices of a denied spirituality in a democratic South Africa. Idutywa: Icamagu Institute

Ndlovu JJM (1991). "The place of African Traditional Religious Heritage in Religious Education Curricula". In Nondo, S J (ed). Multifaith Issues and approaches in religious education with special reference to Zimbabwe, Utrecht: Rijksuniversiteit

Oladimeji O (1980). African Traditional Religion. Nigeria: Hesanmi Press \& Sons (Nigeria) LTD.

Parrinder G (1976). African Traditional Religion. USA: Greenwood Press

Zvabva O (1991). "Development of Research in African Traditional Religions". In S Nondo (ed) Multifaith Issues and Approaches in Religious Education with special Reference to Zimbabwe. Utrecht:

Rijksuniversiteit.

\section{Other references}

The Constitution of the Republic of South Africa. 1996

Meat Safety Act, 2000 (Act No. 40 of 2000)Act No. 19 of 2002. Commission for the Promotion and

Protection of the Rights of Cultural, Religious and Linguistic Communities Act, 2002) 